\title{
The impact of health care restructuring on nosocomially acquired blood stream infections
}

\author{
Geoffrey D Taylor MD FRCPC ${ }^{1,2}$, Margaret McKenzie BScN ${ }^{2}$, Teresa Kirkland BScN ${ }^{2}$, \\ Maureen Buchanan-Chell BScN${ }^{2}$, Rhoda Wiens $\mathrm{BSCN}^{2}$
}

GD Taylor, M McKenzie, T Kirkland, M Buchanan-Chell, $R$ Wiens. The impact of health care restructuring on nosocomially acquired blood stream infections. Can J Infect Dis 2000;11(1):29-32.

OBJECTIVE: To assess the impact of the health care restructuring, which occurred in Alberta in 1995, on the occurrence of nosocomial blood stream infection and risk factors for these infections at the University of Alberta Hospital.

PATIENTS AND METHODS: Changes in patient population, hospital bed numbers, admissions and hospital days for 1993 and 1994 (1993/94) were compared with those for 1996 and 1997(1996/97). Central venous catheter (CVC) use in intensive care units (ICU), days of total parenteral nutrition (TPN) and hemodialysis were compared for the two time periods. Prospectively collected data obtained by monitoring blood culture results on nosocomial blood stream infections in 1993/94 were compared with those obtained in 1996/97.

RESULTS: Hospital bed number fell by 10\% between 1993/94 and 1996/97. Annual admissions fell by 19\% and patient days by $17 \%$. Some services markedly increased patient days (neurosurgery $49 \%$, nephrology $30 \%$, orthopedic surgery $24 \%$ ), and others markedly reduced patient days (obstetrics and gynecology 99\%, ophthalmology 100\%, adult medicine $41 \%$, general paediatrics $38 \%$ ). ICU use of CVCs increased by $41 \%$, TPN days increased by $25 \%$ and hemodialysis runs increased by $9 \%$. Annual nosocomial blood stream infections increased by $31 \%$ and the annual rate per 10,000 patient days increased by $60 \%$. TPN-related blood stream infection rates and ICU CVC infection rates did not change from 1993/94 to 1996/97.

CONCLUSIONS: Hospital restructuring has been associated with a $31 \%$ increase in nosocomial blood stream infection number and a $60 \%$ increase in rate. The increase has been associated with a change in patient populations and increases in risk factors for blood stream infection.

Key Words: Bacteremia; Epidemiology; Nosocomial infection; Restructuring

\section{Impact de la restructuration des soins de santé sur la septicémie nosocomiale}

OBJECTIF : Évaluer l'impact de la restructuration des soins de santé de 1995, en Alberta, sur les cas de septicémie nosocomiale et sur les facteurs de risque à l'égard de cette infection au University of Alberta Hospital.

PATIENTS ET MÉTHODES : Les changements relatifs à la population de patients, au nombre de lits d'hôpitaux, d'admissions et de jours d'hospitalisation de 1993 et 1994 (1993-94) ont été comparés à ceux de la période 1996 et 1997 (1996-97). Le recours aux cathéters veineux centraux (CVC) dans les unités de soins intensifs (USI), le nombre de jours de nutrition parentérale totale (NPT) et d'hémodialyse ont été comparés pour les deux périodes. On a comparé les données prospectives sur les septicémies nosocomiales à partir d'un examen des résultats des hémocultures de 1993-94 et de 1996-97.

RÉSULTATS : Le nombre de lits d'hôpitaux a diminué de 10 \% entre 1993-94 et 1996-97; le nombre annuel d'admissions

voir page suivante

\footnotetext{
${ }^{1}$ University of Alberta; ${ }^{2}$ University of Alberta Hospital, Edmonton, Alberta

Correspondence and reprints: Dr GD Taylor, WMC 2E4.11, University of Alberta Hospital, 8440 - 112 Street, Edmonton, Alberta T6G 2B7.

Telephone 780-407-7786,fax 780-407-7137,e-mail geoff.taylor@ualberta.ca

Received for publication February 24, 1999. Accepted July 28, 1999
} 
a diminué de $19 \%$ et le nombre de jours-patients, de $17 \%$. Certains services ont nettement augmenté leur nombre de jours-patients (neurochirurgie, $49 \%$; néphrologie, $30 \%$; chirurgie orthopédique, $24 \%$ ) et d'autres ont nettement réduit leur nombre de jours-patients (obstétrique et gynécologie, $99 \%$; ophtalmologie, $100 \%$, médecine de l'adulte $41 \%$; pédiatrie générale, $38 \%$ ). L'utilisation de CVC aux USI a augmenté de $41 \%$. Le nombre de jours de NPT a augmenté de 25 $\%$ et la durée des hémodialyses a augmenté de $9 \%$. Le taux annuel de septicémies nosocomiales a augmenté de $31 \%$ et le taux annuel par 10000 jours-patients a augmenté de $60 \%$. Le taux de septicémies liées à la NPT et les taux d'infections liées aux CVC dans les USI n'ont pas changé entre 1993-94 et 1996-97.

CONCLUSION : La restructuration des hôpitaux a été associée à une augmentation de 31 \% des cas de septicémie nosocomiale et à une hausse du taux de l'ordre de $60 \%$. L'augmentation a été associée à un changement des populations de patients et à une multiplication des facteurs de risque de septicémie.

$\mathrm{H}$ ealth care delivery has always undergone evolutionary change as disease patterns evolve and their treatments are modified. In the past decade, Canadians have witnessed much more rapid and revolutionary change in health care delivery than has been previously experienced. Some of the changes include a reduction in global spending by the government on health care services and a transfer of a great deal of care from hospitals to community settings. As a consequence, hospitals across the country have been reduced in size and number $(1,2)$. On average, present hospital patient populations are likely more seriously ill than they have been in the past.

Radical changes in health care delivery occurred in Alberta in 1995. Provincial government per capita funding of health care fell by $16 \%$ (3). Individual hospital boards were dissolved, and a smaller number of Regional Health Authorities were formed, responsible for the continuum of health care in their region. In Edmonton, 1995 saw one hospital closed and three were downgraded to community health centres. A 35\% reduction in hospital beds occurred in the Edmonton region that year (4). Where feasible, health care was transferred from the hospital to the community. Two referral hospitals remained with a wider range of 'high intensity' services, one of which was the University of Alberta Hospital (UAH).

At UAH, we wanted to assess the impact of health care restructuring on the occurrence of nosocomial infections. Using prospectively collected data on nosocomial blood stream infections, we compared infections for the two years before restructuring (1993 and 1994) with those for the two years after restructuring (1996 and 1997).

\section{PATIENTS AND METHODS}

Hospital volume and acuity: To assess trends in hospital patient care volume, the number of hospital inpatient beds, annual admissions and patient days were obtained comparing 1993 and 1994 (1993/94) 1996 and 1997 (1996/97). To assess changes in the hospital population, the proportion of inpatient beds designated as intensive care unit (ICU) beds and the distribution of patient days by medical service were determined. To assess changes in the prevalence of risk factors for blood stream infection, hospital wide days of use of total parenteral nutrition (TPN) $(5,6)$ supplied by the hospital pharmacy, number of hemodialysis runs performed annually by the hemodialysis unit (7-9) and central venous catheter (CVC) days of use by ICUs $(10,11)$ were determined. Assessment of the extent of mechanical ventilation use (ventilator days) was not available, nor were CVC days of use outside of the ICU.
Nosocomial blood stream infections and rates: Nosocomial blood stream infections were identified through the prospective monitoring of clinical microbiology laboratory reports by the hospital's infection control staff, as previously described $(12,13)$. Centers for Disease Control and Prevention definitions of infection were used to distinguish nosocomial infections from community-acquired infections or blood culture contaminants (14). Infection rates were calculated using patient days and patient admission denominators supplied by the hospital's information systems department. ICU CVC-associated blood stream infection rates were calculated using CVC day denominators supplied by the ICU staff $(11,15)$. Episodes of primary bacteremia occurring in outpatients undergoing chronic hemodialysis in the hospital hemodialysis unit were included in the numerator. Episodes of hemodialysis-related bacteremia occurring in ICU patients were attributed to the ICU, and included under the category primary blood stream infection. Infections and infection rates occurring in the two years before restructuring (1993 and 1994) were compared with infections and infection rates occurring during the two years after restructuring (1996 and 1997). Statistical comparisons of rates were performed by EPI INFO, version $6.04 \mathrm{~b}$ (Centers for Disease Control and Prevention, Atlanta, Georgia) and by the statistical program of Automated Infection Control Expert (Infection Control and Prevention Analysts Inc, Austin, Texas).

\section{RESULTS}

Hospital patient volume and acuity: Although between $1993 / 94$, and 1996/97, there was a $10 \%$ decline in patient beds (645 to 586), the number of ICU beds was unchanged and slightly increased as a proportion all beds, from $13.2 \%$ to $14.7 \%$. Annual hospital admissions fell from 29,085 to 23,597 (19\%). Overall, there was a $17 \%$ decline in annual hospital patient days (29,085/year to $23,597 /$ year). The distribution of hospital days by medical service radically changed. Some services markedly increased their patient days (neurosurgery 49\%, nephrology $30 \%$, orthopedic surgery $24 \%$ and general surgery $16 \%$ ), others markedly reduced patient days (obstetrics and gynecology $99 \%$, ophthalmology $100 \%$, general pediatrics $38 \%$, adult medicine $41 \%$, neonatology $25 \%$ and psychiatry $16 \%$ ) and a few remained relatively unchanged (cardiology $4 \%$ increase, hematology $4 \%$ decrease). Within the hospital's seven ICUs, the use of CVCs increased from 9852 days/year before restructuring to 13,876 year after restructuring (41\%). The hospital's hemodialysis unit increased the number of dialysis runs given by $9 \%$, from 19,294 /year to 20,963 /year and inpatient use of TPN increased from 6632 days/year to 8322/year (25\%). 
TABLE 1

Nosocomial blood stream infection rates for selected medical services at the University of Alberta Hospital

\section{Rate/10,000 patient days}

\begin{tabular}{lccc} 
Service & $\mathbf{1 9 9 3 / 1 9 9 4}$ & $\mathbf{1 9 9 6 / 1 9 9 7}$ & $\mathbf{P}$ \\
\hline General surgery & 23.4 & 18.6 & $>0.05$ \\
Neurosurgery & 9.8 & 15.8 & $>0.05$ \\
Orthopedic surgery & 5.8 & 2.6 & $>0.05$ \\
Cardiac surgery & 40.7 & 46.8 & $>0.05$ \\
Cardiology* & 12.7 & 20.6 & $>0.05$ \\
Nephrology & 70.8 & 124.8 & $<0.001$ \\
Hematology* & 54.4 & 86.2 & 0.04 \\
General paediatrics & 4.6 & 24.6 & 0.009 \\
Adult medicine & 5.6 & 12.0 & 0.002 \\
All services & 8.2 & 13.3 & $<0.001$ \\
\hline
\end{tabular}

*Adult and paediatric

Nosocomial blood stream infections: In the two years before restructuring, 481 nosocomial blood stream infections occurred, and 630 occurred in the two years following restructuring, an increase of $31 \%$. Increases occurred in both ICU (242 to 276 infections, $14.0 \%$ ) and non-ICU units (240 to 354 infections, 47.5\%). Infections increased in the dialysis unit from 13 in 1993/94 to 57 in 1996/97, a 338\% increase. The hospital wide annual infection rate increased from 8.3/1000 admissions to $13.3 / 1000$ admissions (rate ratio $1.6,95 \% \mathrm{CI} 1.4$ to $1.8)$, an increase of $60 \%$. The rate significantly increased for primary infections (largely attributable to various forms of intravascular devices), from $4.9 / 1000$ admissions to $8.2 / 1000$ admissions (rate ratio $1.6,95 \% \mathrm{CI} 1.4$ to 1.9 ), and secondary infections, from 3.3/1000 admissions to 5.1/1000 admissions (rate ratio $1.6,95 \% \mathrm{CI} 1.3$ to 1.9 ). Within the group of secondary infections, blood stream infection from a lower respiratory source increased by the largest amount from 7.0/1000 admissions to $15.0 / 1000$ admissions ( $\mathrm{P}>0.05)$. Infection rates were also calculated using hospital patient days as a denominator for medical services and each of the ICUs (Tables 1,2). Within ICUs, the authors were able to calculate CVC-associated blood stream infection rates using central line days as the denominators. While the total number of ICU CVC-associated infections increased from 130 before restructuring to 195 after restructuring, none of the ICUs increased their CVC infection rates using CVC days as the denominator (data not shown). For the ICUs as a group, the pooled CVC infection rate was $7.3 / 10,000 \mathrm{CVC}$ days before and 7.1/10,000 after restructuring $(\mathrm{P}>0.05)$. TPN-related infections did not change in number (121 in 1993/94 and 122 in 1996/97) and decreased in rate from $88.7 / 1000$ TPN days to $73.3 / 1000$ TPN days $(\mathrm{P}=0.08)$.

Table 3 shows organism-specific changes for seven different microorganisms that increased in number or rate. For four different organism groups (Staphyloccus aureus, Enterococcus species, Candida species and Pseudomonas species), the rate increase was statistically significant. The greatest increase occurred for infection due to Enterococcus species, from 30 infections or $0.5 / 1000$ admissions before to 82 infections or $7.8 / 1000$ after restructuring (rate ratio $3.6,95 \%$ CI 1.3 to 5.5 ).
TABLE 2

Intensive care unit nosocomial blood stream infections at the University of Alberta Hospital

\begin{tabular}{lccc}
\hline & \multicolumn{2}{c}{ Rate/10,000 patient days } & \\
Unit & $\mathbf{1 9 9 3 / \mathbf { 1 9 9 4 }}$ & $\mathbf{1 9 9 6 / 1 9 9 7}$ & $\mathbf{P}$ \\
\hline General adult & 43.3 & 63.1 & $<0.001$ \\
Cardiac surgery & 53.1 & 50.2 & $>0.05$ \\
Neonatal & 54.4 & 47.3 & $>0.05$ \\
Neurosurgery & 15.4 & 47.3 & $>0.05$ \\
Burn & 19.2 & 76.6 & $<0.001$ \\
Paediatric & 92.1 & 69.7 & $>0.05$ \\
Coronary care & 16.4 & 25.3 & $>0.05$ \\
\hline
\end{tabular}

TABLE 3

Organism-specific nosocomial blood stream infections at the University of Alberta Hospital

\begin{tabular}{lcccc}
\hline & \multicolumn{2}{c}{$\mathbf{1 9 9 3 / 1 9 9 4}$} & \multicolumn{2}{c}{$\mathbf{1 9 9 6 / 1 9 9 7}$} \\
Number of & $\begin{array}{c}\text { Rate/10,000 } \\
\text { Odmissions }\end{array}$ & $\begin{array}{c}\text { Number of } \\
\text { episodes }\end{array}$ & $\begin{array}{c}\text { Rate/10,000 } \\
\text { admissions }\end{array}$ \\
\hline $\begin{array}{c}\text { Ooagulase- } \\
\text { negative } \\
\text { staphylococci }\end{array}$ & 187 & 3.1 & 180 & 3.8 \\
$\begin{array}{c}\text { Staphyloccocus } \\
\text { aureus }\end{array}$ & 82 & 1.4 & 124 & $2.6^{*}$ \\
$\begin{array}{c}\text { Enterococcus } \\
\text { species }\end{array}$ & 30 & 0.5 & 87 & $1.8^{+}$ \\
$\begin{array}{c}\text { Candida } \\
\text { species }\end{array}$ & 29 & 0.5 & 40 & $0.8^{\ddagger}$ \\
$\begin{array}{c}\text { Escherichia coli } \\
\text { Klebsiella } \\
\text { species }\end{array}$ & 40 & 0.7 & 46 & 1.0 \\
$\begin{array}{c}\text { Pseudomonas } \\
\text { species }\end{array}$ & 17 & 0.5 & 36 & 0.8 \\
$\begin{array}{c}\text { Enterobacter } \\
\text { species }\end{array}$ & 16 & 0.3 & 17 & 0.4 \\
\hline
\end{tabular}

*Rate ratio 1.9 (95\% Cl 1.4 to 2.5$) ;{ }^{\dagger}$ Rate ratio 3.6 (95\% Cl 2.3 to 5.5);

${ }^{\ddagger}$ Rate ratio 1.7 (95\% Cl 1.03 to 2.82 ); ${ }^{\S}$ Rate ratio 2.0 (95\% Cl 1.1 to 3.7 )

\section{DISCUSSION}

Health care restructuring in 1995 radically transformed our hospital, with a resultant impact on nosocomial blood stream infections. While there was a decrease in bed number, admissions and patient days at the hospital, patient populations shifted from groups at lower nosocomial infection risk (eg, ophthalmology, psychiatry, internal medicine and paediatrics) to groups at higher risk (eg, surgical patients, nephrology). As a result, markers of nosocomial blood stream infection risk, such as ICU CVC days, TPN days and the use of hemodialysis, actually increased.

This increase in risk was associated with widespread increases in nosocomial blood stream infection including both ICU and non-ICU infections, primary and a range of secondary infections, and the increased frequency of wide spectrum of bacterial and fungal microbial causes of blood stream infections. The increase in absolute numbers of infections indicates that the increases were real and not simply a reflection of transfer of low risk patients, destined never to have an infection, to the community setting. This increase was likely a 
result of the transfer of high risk patient groups to the hospital that had been previously treated elsewhere in our region.

We only measured nosocomial infections resulting in blood stream infection, more than half of which were primary, ie, not attributable to another organ system infection. Nevertheless, it is possible that an increase in nonbacteremic nosocomial infections may have also occurred, because blood stream infections secondary to a range of nosocomial infections (pneumonia, urinary tract, surgical site) also increased measurably in frequency by an amount identical to that of primary infections.

of particular concern is that the greatest increases in infection rates occurred for organisms that are difficult to treat (candida, pseudomonas) or increasingly antimicrobial resistant (Enterococcus species, $S$ aureus). To date, we have not experienced blood stream infection due to methicillin-resistant $S$ aureus or vancomycin-resistant enterococcus. However, the spread of these resistant strains to our hospital and the displacement of the rapidly increasing numbers of their antimicrobial sensitive counterparts would be a seriously negative development for our patient population.

What do our data say about the quality of hospital care delivered? In previously published data (12), an increase in the risk-adjusted hemodialysis infection rate was shown during and following restructuring, attributable to an increased need to carry out hemodialysis via CVCs. Increases in dialysis- related infections accounted for $29.5 \%$ of the total increase in infections between the two time periods. In the present study, using appropriate risk adjustment techniques (15), we have shown stable rates for ICU CVC infection and infections associ-

\section{REFERENCES}

1. Shamian J, Lightstone EY. Hospital restructuring initiatives in Canada. Med Care 1997;35:OS62-9.

2. Anderson GM. Hospital restructuring and the epidemiology of hospital utilization: recent experience in Ontario. Med Care 1997;35:OS93-101.

3. Alberta Ministry of Health. Annual Report 1996 - 1997. Edmonton: Alberta Provincial Government, 1997.

4. Capital Health. Annual Report 1995/96. Edmonton: Capital Health Authority, 1996.

5. Wistbacka JO, Nuutinen LS. Catheter-related complications of total parenteral nutrition (TPN): a review. Acta Anaesth Scand 1985;29:84-8.

6. Rannem T, Laefoged K, Hegnhoj F, Hylander Moller E, Bruun B, Jarnum S. Catheter related sepsis in long-term parenteral nutrition with broviac catheters. An evaluation of different disinfectants. Clin Nutr 1990;9:131-6.

7. Churchill DN, Taylor DW, Cook RJ, et al. Canadian hemodialysis morbidity study. Am J Kidney Dis 1992;19:214-34.

8. Goldman M, Vanherweghem JL. Bacterial infection in chronic hemodialysis patients: Epidemiologic and pathophysiologic aspects. Adv Nephrol 1990;19:315-32.

9. Hoen B, Paul-Dauphin A, Dominique H, Kessler M. EPIBACDIAL: A multicenter prospective study of risk factors for bacteremia in chronic hemodialysis patients. J Am Soc Nephrol 1998:9:869-76.

10. Fridkin SK, Welbel SF, Weinstein RA. Magnitude and prevention ated with TPN, suggesting that the quality of care has not changed for these patient groups. These data suggest that the restructuring of health care delivery can be accomplished without a negative impact on the frequency of infectious complications, but that planning of change and monitoring of results are necessary to ensure that this occurs.

\section{CONCLUSIONS}

Restructuring of the UAH was associated with measurable increases in the patient population risk of nosocomial blood stream infection, and resulted in a $31 \%$ increase in number and a $60 \%$ increase in rate of these infections. Because health care restructuring is occurring across Canada, it seems likely that our experience will be replicated elsewhere. As a result, the nature of hospital care has changed. Future hospital populations will be more seriously ill, undergo more invasive procedures and turn over more quickly than in the past. These changes have implications for health care planners. For example, nurse to patient ratios suitable for a mix of more and less seriously ill patients may be inadequate for patient groups who are all seriously ill. Finally, there are implications for hospital infection control programs (of proven value in reducing rates of nosocomial infection); these program will need to be augmented to address the increasing infection risk of current hospitalized patient populations and to assess the impact of changing health care delivery. Previously recommended infection control staffing guidelines for acute care hospitals (one infection control practitioner to 250 beds) came from data collected in the 1970s, and this number is inadequate for the needs of current hospital patient populations $(16,17)$.

of nosocomial infections in the intensive care unit. Infect Dis Clin North Am 1997;11:479-96.

11. Jarvis WR, Edward JR, Culver DH, et al. Nosocomial infection rates in adult and pediatric intensive care units in the United States. Am J Med 1991;91(Suppl 3B):185-91.

12. Taylor GD, McKenzie M, Buchanan-Chell M, Caballo L, Chui L, Kowalewska-Grochowska K. Central venous catheters as a source of hemodialysis-related bacteremia. Infect Control Hosp Epidemiol 1998;19:643-6.

13. Taylor GD, Buchanan-Chell M, Kirkland T, McKenzie M, Wiens R. Nosocomial Gram-negative bacteremia. Int J Infect Dis 1997;1:202-5.

14. Garner JS, Jarvis WR, Emori TG, Horan TC, Hughes JM. CDC definitions for nosocomial infections, 1988. Am J Infect Control $1988 ; 16: 128-40$.

15. Gaynes RP, Solomon S. Improving hospital-acquired infection rates: The CDC experience. Jt Comm J Qual Improv 1996;22:457-65.

16. Haley RW, Culver DH, White JW, et al. The efficacy of infection surveillance and control programs in prevention of nosocomial infection in US hospitals. Am J Epidemiol 1985;121:182-205.

17. Scheckler WE, Brimhall D, Buch AS, et al. Requirements for infrastructure and essential activities of infection control and epidemiology in hospitals: A consensus panel report. Infect Control Hosp Epidemiol 1998;19:114-24. 


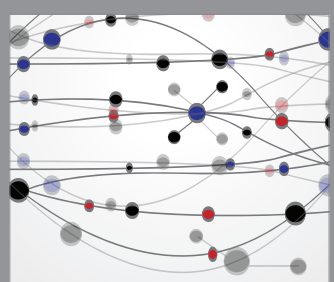

The Scientific World Journal
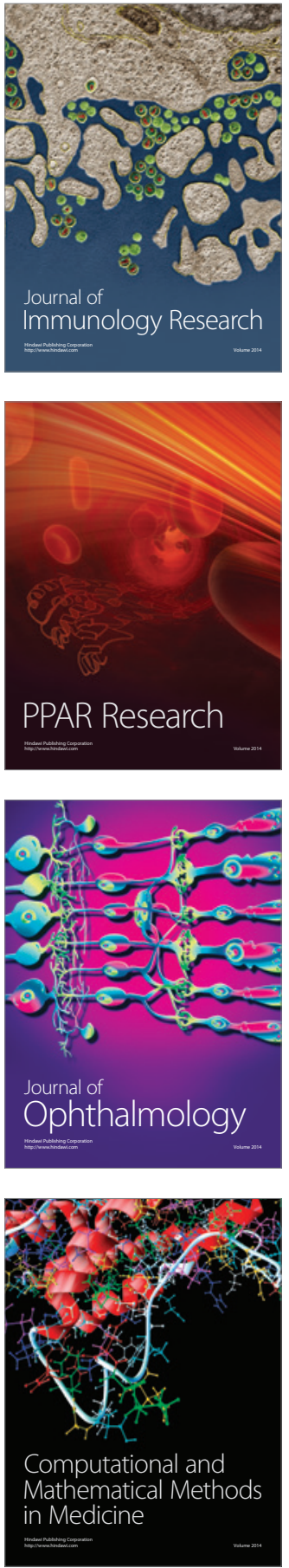

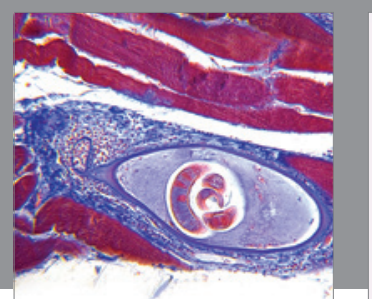

Gastroenterology Research and Practice

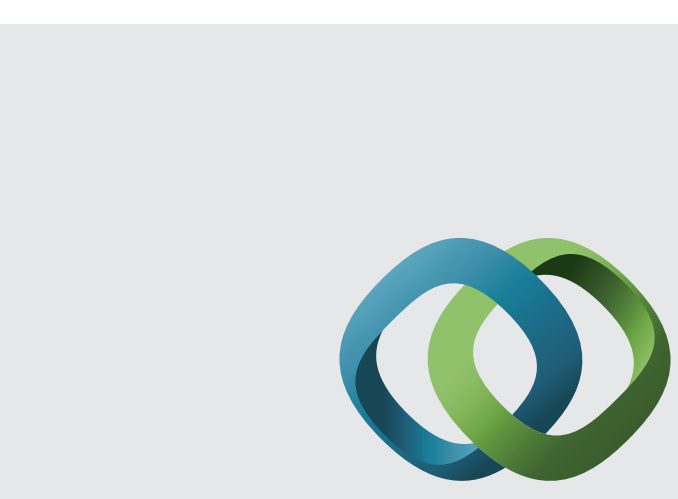

\section{Hindawi}

Submit your manuscripts at

http://www.hindawi.com
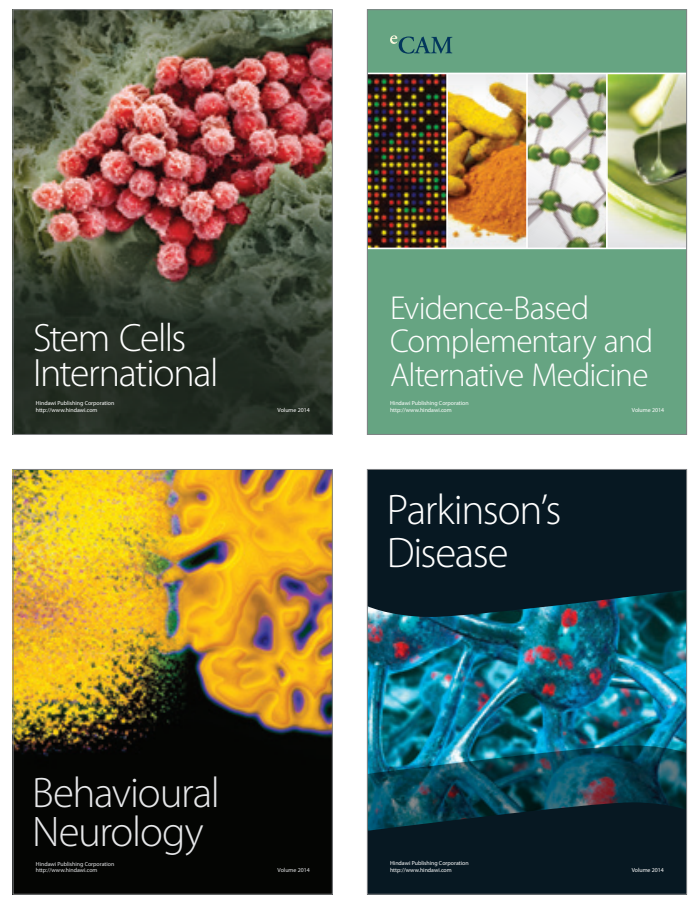
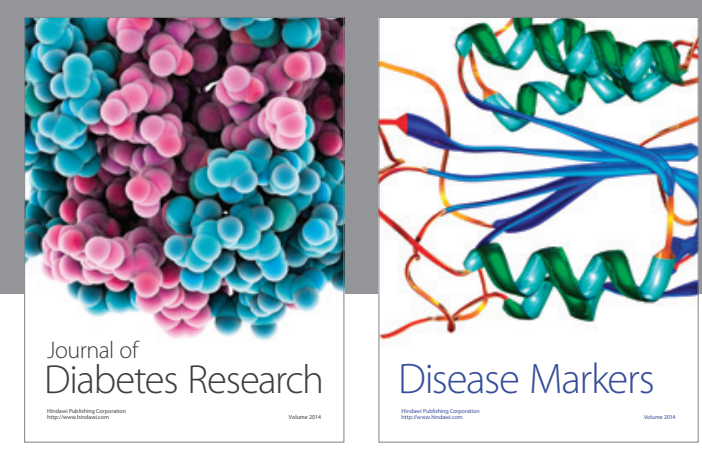

Disease Markers
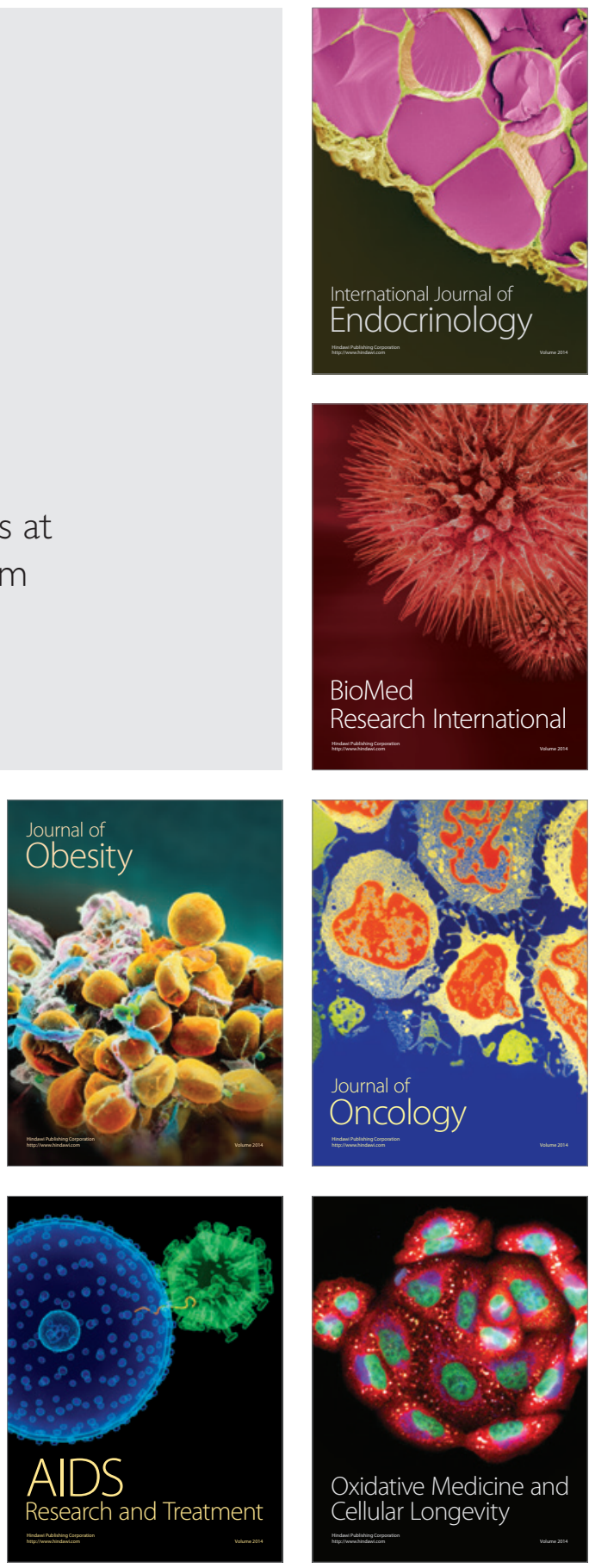